\title{
Toxicological Studies of Chaturmukha Rasa, an Ayurvedic Formulation
}

\author{
Akansha Sharma ${ }^{1}$, Raj Kumar Tiwari², Vikas Sharma ${ }^{2}$, Ravindra Kumar Pandey ${ }^{1}$, \\ Shiv Shankar Shukla ${ }^{1, *}$
}

${ }^{1}$ Columbia Institute of Pharmacy, Raipur, Chhattisgarh, INDIA.

${ }^{2}$ Department of Pharmacology, Columbia Institute of Pharmacy, Raipur, Chhattisgarh, INDIA.

\begin{abstract}
Objectives: Chaturmukha Rasa is aspecial, Ayurvedic mercurial preparation broadly used by local practitioners and traditional healers. This research is an endeavour to perform acute and chronic oral toxicity assessment of Chaturmukha Rasa along with an adjuvant Erandapatra (solidified aqueous extract of Ricinus communis Linn.) in wistar rats. Methods: Oral acute toxicity study was performed at $2000 \mathrm{mg} / \mathrm{kg}$ orally, which was considered as limit dose. The chronic toxicity study was carried out with administration of Chaturmukha Rasa with adjuvant at three therapeutic equivalent doses i.e. TED (45 mg/kg, orally), TEDx5 (225 mg/kg, orally) and TEDx10 (450 mg/kg, orally) for 90 daysand an additional recovery group of therapeutic equivalent dose $\times 10$ for 30 -day observation after the treatment period. Results: The result of acute toxicity showed that drug did not create any signs and symptoms of toxicity or no mortality was shown to an oral dose of $2000 \mathrm{mg} / \mathrm{kg}$ in rats. The results of chronic toxicity study showed that the drug even at level as high as dose of TEDx10 had no significant effect at all on haematological and body weight parameters. The drug but, at dose of TEDx10 showed mild to moderate unfavourable changes in kidney and liver. The experiential changes were not seen at the lower dose levels. Hence, it is suggested that the Chaturmukha Rasa, along with the adjuvant prepared as per the traditional method, is secure for utilization at the therapeutic dose level.
\end{abstract}

Key words: Chaturmukha Rasa, Erandapatra, Ricinus communis, Bhasma, Toxicity.

\section{INTRODUCTION}

Ayurveda is considered as ancient Indian traditional system of medicine. The medicinal treatment by it shares a great historical background. It had enhanced the living conditions of various community of the world. ${ }^{1}$ Many formulations mentioned in Ayurveda make use of herbs along with minerals especially mercury, iron, sulphur etc. These herbo-metalic preparations are prepared by unique process which mainly involves Shodhana and marana. The Indian traditional practioners have developed these processes to detoxify the combinations with the help of chemical transformation to modify the therapeutic prospective of the combinational formulations. Extensive use of these formulations from decades without any unwanted effect is the best proof of their therapeutic efficacy and safety. The main problem with these formulations is of non-existence of preclinical or clinical data to support such claims. Preclinical or clinical data of Ayurvedic formulations provides scientific basis for their traditional use and to prove that they are safe and efficacious., ${ }^{2,3}$ Chaturmukha Rasa is an Ayurvedic medicine available in tablet form. It is used in the treatment of asthma, anemia, diabetes, digestion power, relieves anemia, diabetes, asthma, abdominal colic, anorexia, hiccups, dyspepsia, epilepsy, gout, herpes, abscess, psychotic disorders and hemorrhoids. It mainly consists of $10 \mathrm{~g}$ fine powder each of:
Submission Date: 25-03-2019; Revision Date: 14-06-2019; Accepted Date: 04-09-2019

DOI: 10.5530/ijper.53.4.132 Correspondence: Dr. Shiv Shankar Shukla, Professor, Department of herbal Drug Development, Columbia Institute of Pharmacy, Raipur-490042, Chhattisgarh, INDIA. Phone: +91-9826124442 E-mail: shivpharma007@ gmail.com

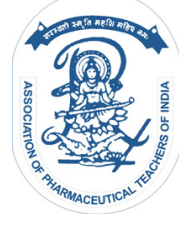

www.ijper.org 
Shuddha Parada (Herbal purified Mercury), Shuddha Gandhaka (Herbal purified Sulphur), Loba Bhasma (Bhasma prepared from Iron), Abhraka Bhasma (Purified and processed Mica), Kumari (Aloe vera juice extract), Errand (Castor Ricinus communis leaves). Fine power of above ingredient is ground with juice extract or decoction, made into paste and pills are prepared. ${ }^{4}$ Since reports of toxicity evaluation of this classical preparation (along with the adjuvant) was not available during extensive literature review, it was thought worthwhile to undertake the detailed toxicity assessment in albino rats.

\section{MATERIALS AND METHODS}

Aloe vera and Ricinus communis were collected from the botanical garden of Columbia Institute of Pharmacy, Raipur, C.G. The plant material were authenticated and voucher specimen of each submitted to Pharmacology Laboratory of Columbia Institute of Pharmacy. Chaturmukha Rasa was prepared in the Department of Pharmacognosy (Table 1), Columbia Institute of Pharmacy, Raipur, C.G; and Sops were prepared and documented. All chemical used in this study were of analytical grade.

\section{Experimental Animals}

Wistar albino rats of either sex weighing $200 \pm 20 \mathrm{~g}$ body weight were used for the study. The animals were maintained under ideal husbandry conditions in terms of standard conditions of temperature $\left(23 \pm 2^{\circ} \mathrm{C}\right)$, relative humidity (50 to 60\%) and exposed to $12 \mathrm{hr}$ light-anddark cycles. All animals were exposed to the same environmental conditions and were maintained on standard diet and drinking water ad libitum. The experimental protocol was approved by the Institutional Animal Ethical Committee (IAEC/2015-16/062) as per the guideline of Committee for the Purpose of Control and Supervision on Experiments on Animals, India.

\section{Table 1: Ingredients of Ayurvedic Formulation.}

\begin{tabular}{|c|c|c|}
\hline Ayurvedic Name & Scientific name & Quantity \\
\hline Rasa (prada) suddha & Mercury & 1 part \\
\hline Gandhakasuddha & Sulphur & 1 part \\
\hline Loha- bhasma & Iron & 1 part \\
\hline $\begin{array}{c}\text { Abhra (abhraka) } \\
\text { bhasma }\end{array}$ & Mica & 1 part \\
\hline $\begin{array}{c}\text { Kanya (kumara) } \\
\text { swarasa }\end{array}$ & $\begin{array}{c}\text { Aloe barbadensis } \\
\text { Mill. }\end{array}$ & $\begin{array}{c}1 / 4 \text { part, } \\
\text { formardana }\end{array}$ \\
\hline Erandapatra & $\begin{array}{c}\text { Ricinus communis } \\
\text { Linn. }\end{array}$ & $\begin{array}{c}\text { Q.S. for } \\
\text { avestana }\end{array}$ \\
\hline
\end{tabular}

\section{Dose Selections}

The therapeutic dose of Chaturmukba Rasa is $125 \mathrm{mg} / \mathrm{d}^{5}$ as per the classical guideline and should be administered with the adjuvant as solidified aqueous extract of Ricinus communis $(375 \mathrm{mg} / \mathrm{d})$. Hence the total dose of the drug with adjuvant is $500 \mathrm{mg} / \mathrm{d}$. The suitable dose for the rat was found to be $45 \mathrm{mg} / \mathrm{kg}$ rat, calculated by referring to table of Paget and Barnes ${ }^{6}$ and this was considered as therapeutic equivalent dose, TED. The test drug along with adjuvant was administered orally with the help of cannula, in the form of suspension in honey and distilled water solution.

\section{Acute Toxicity Studies}

Young, healthy, non-pregnant Wistar-strain albino, female rats were selected and acclimatized for seven days before the experiment. The Chaturmukha Rasa along with adjuvant was orally administered at a limit dose of $2000 \mathrm{mg} / \mathrm{kg}$ to overnight fasted female rats in sequential manner as per OECD 425 guidelines. ${ }^{7}$ The rats were observed closely for behavioral changes, signs and symptoms of toxicity and mortality continuously for the first six h; and thereafter, periodically up to $14 \mathrm{~d}$. The body weight of each rat was noted on the last day and the rats were sacrificed. The abdomen was opened through mid-line incision to record the autopsy changes, followed by dissecting the important organs for histopathological changes.

\section{Chronic Toxicity Studies}

The chronic toxicity study was carried out by standard guideline with modification as per experimental need. ${ }^{8}$ Rats were randomized into six groups of six rats in each with three males and three females. Group (I) was kept as control group, received vehicle as honey solution in distilled water (5 ml $/ \mathrm{kg}$, orally). Group (II) to (IV) were administered with test drug Chaturmukha Rasa along with adjuvant at TED (45 mg/kg, orally), TED $\times 5$ (225 mg/kg, orally) and TED $\times 10(450 \mathrm{mg} / \mathrm{kg}$, orally), respectively. The suspensions of test drugs were administered orally once-a-day for 90 consecutive days in main study. Additional six animals were kept in satellite control group (V) and in the recovery TED $\times 10$ treated groups (VI) for observation after the treatment period, for reversibility or persistence of any toxic effects. The duration of post-treatment period was fixed as $30 \mathrm{~d}$ (total of $120 \mathrm{~d}$, including $90 \mathrm{~d}$ treatment period and $30 \mathrm{~d}$ recovery period). All the animals were dosed with constant dose volume of $5 \mathrm{ml} / \mathrm{kg}$, orally.

The rats were observed daily, carefully for any overt and apparent signs and symptoms of toxicity. The bodyweight change of an individual rat was noted initially 
and thereafter weekly during the study period. At the end of experimental periods, blood was withdrawn by the retro-orbital puncture under light-ether anesthesia using capillary tube for estimation of serum biochemical and hematological parameters. The body weight of each rat was noted on last day and rats were sacrificed. The abdomen was opened through mid-line incision to record the autopsy changes followed by dissecting out the important organs.

Hematological analysis was performed using an automatic hematological analyzer (Swelab, Sweden). The parameters were total red blood cell (RBC), hemoglobin ( $\mathrm{Hb})$, packed cell volume (PCV), mean corpuscular volume (MCV), mean corpuscular hemoglobin $(\mathrm{MCH})$, mean corpuscular hemoglobin concentration (MCHC), white blood cell (WBC), neutrophils percentage $(\% \mathrm{~N})$, lymphocyte percentage $(\% \mathrm{~L})$, eosinophil's percentage, monocyte percentage and platelet count (PC).

Serum bio-chemical parameters were carried out using fully automated biochemical random access analyser (BS-200, Lilac Medicare Pvt. Ltd., Mumbai). The parameters were blood glucose, ${ }^{9}$ urea,${ }^{10}$ creatinine, ${ }^{11}$ total cholesterol ${ }^{12}$ HDL-cholesterol, ${ }^{13}$ triglyceride, ${ }^{14}$ VLDLcholesterol, LDL-cholesterol, ${ }^{15}$ total protein, ${ }^{16}$ albumin, globulin, ${ }^{17}$ alkaline Phosphatase, ${ }^{18}$ SGOT, ${ }^{19}$ SGPT,${ }^{20}$ uric acid, ${ }^{21}$ direct bilirubin, ${ }^{22}$ total bilirubin ${ }^{23}$ and serum calcium. ${ }^{24}$

The important internal organs were carefully dissected namely liver, kidney. After noting for any signs of gross lesion and ponderable changes of major organs, all were transferred to $10 \%$ phosphate buffered formalin solution for fixation and later on subjected to dehydrating, wax embedding, sectioning and staining with haematoxylin and eosin ( $\mathrm{H}$ and $\mathrm{E})$ for histological evaluation by light microscopy. The slides were viewed under trinocular research Carl-Zeiss's microscope at various magnifications to note down the changes in the microscopic features of the tissues.

\section{Statistical Analysis}

The data is expressed as mean \pm standard error of mean for six rats per experimental group. One-way analysis of variance (ANOVA) was used to compare the mean values of quantitative variables among the groups, followed by Dunnet's multiple $t$-test for unpaired data to determine significant difference between groups at $P<0.05$.

\section{RESULTS AND DISCUSSION}

Acute toxicity study of test drug was carried out to record immediate adverse signs and symptoms of drug in female rats at dose levels that are several folds higher than the therapeutic equivalent dose. Administration of Chaturmukha Rasa along with adjuvant did not affect any behavioral changes and other parameters observed during the acute toxicity test in female rats. No signs and symptoms of toxicity and mortality were observed up to oral dose of $2000 \mathrm{mg} / \mathrm{kg}$ of test drug in rats. Further, drug did not affect the cytoarchitecture of major organs like kidney, liver which suggest that $\mathrm{LD}_{50}$ value may be higher than $2000 \mathrm{mg} / \mathrm{kg}$ by oral route. As per UN classification, any substance, which has oral $\mathrm{LD}_{50}$ of more than $2000 \mathrm{mg} / \mathrm{kg}$ is considered as low hazard potential and categorized as UN 6.1 PG III. ${ }^{25}$ Thus as per the above criterion Chaturmukha Rasa along with adjuvant can be categorized as substances with low health hazard potential (Class 4 of GHS and UN 6.1 PG III).

There were no behavioral changes observed in Chaturmukha Rasa treated groups during the course of chronic toxicity study. No symptoms of toxicity and mortality were observed in treated groups at TED $\times 10$, TED $\times 5$ and TED dose levels and TED $\times 10$ in the recovery study. Normal body weight gain was observed in control rats during main study ( $90 \mathrm{~d}$ ) as well as recovery study $(120 \mathrm{~d})$. An increase in body weight was found in Chaturmukha Rasa treated groups at all dose levels. Changes in body weight are an important factor to monitor the health of an animal. Loss of body weight is usually the first sign indicating the onset of an adverse effect. The dose, at which body weight loss is by $10 \%$ or more, is considered to be a toxic dose, irrespective of whether or not it is accompanied by any other changes. ${ }^{26}$ The percentage change in body weight pattern in test drug treated groups did not differ significantly from the changes observed in the control groups, which suggest the absence of serious toxic effect of Chaturmukha Rasa during chronic administration in rats.

In liver (Table 1), Chaturmukba Rasa treated group showed minor decrease in relative weight of liver in TED treated group, TEDx 5 and TEDx10 in comparison to the normal control whereas in case of kidney TED and TEDx 5 showed minor decrease in weight but TEDx10 showed significant increase in weight. Normally, decrease in the weight of an organ is indicative of loss of tissue mass in that organ, exception being the secretary organs in which the decrease in weight sometimes is seen along with the increased activity. In this case, the minor decrease in the weight of reproductive organs may be indicative of dissimulation of hormone secretion. In the present study, there were no remarkable changes observed in the relative weight of the organs at higher doses of test drugs. Hence, it may be, understood that the drugs do not tend to produce any serious 


\begin{tabular}{|c|c|c|c|c|c|}
\hline Relative weight & Control group & TED & TED 5 & TEDx10 & Recovery TEDx10 \\
\hline Liver $(\mathrm{g} / 100 \mathrm{~g})$ & $7.08 \pm 0.13$ & $6.86 \pm 0.16$ & $6.85 \pm 0.15$ & $7.04 \pm 0.13$ & $6.9 \pm 0.12$ \\
\hline Kidney (mg/100g) & $1.35 \pm 0.09$ & $1.27 \pm 0.07$ & $1.32 \pm 0.05$ & $1.39 \pm 0.05$ & $1.37 \pm 0.15$ \\
\hline
\end{tabular}

The results are expressed as mean $\pm \mathrm{SEM}$, where $\mathrm{n}=6$. SEM: Standard error of mean. $* P<0.05$, compared with control group.

Table 3: Effect of Test Drugs on Hematological Parameters in Rats Recorded During Chronic Toxicity Study.

\begin{tabular}{|c|c|c|c|c|c|}
\hline Hematological parameters & Control group & TED & TED 5 & TEDx10 & $\begin{array}{c}\text { Recovery } \\
\text { TEDx10 }\end{array}$ \\
\hline Bleeding time & $11.47 \pm 0.32$ & $11.95 \pm 0.22$ & $11.54 \pm 0.29$ & $11.02 \pm 0.28$ & $12 \pm 0.14$ \\
\hline Clotting time & $56.23 \pm 0.72$ & $53.26 \pm 0.94$ & $52.37 \pm 0.63$ & $56.37 \pm 0.69$ & $55 \pm 0.13$ \\
\hline WBC count & $8866.6 \pm 339.6$ & $12963.3 \pm 4127.4$ & $8861.6 \pm 428.3$ & $10531.6 \pm 1452.3$ & $8960.3 \pm 1334.2$ \\
\hline Lymphocyte count & $45.05 \pm 3.4$ & $34.7 \pm 4.4$ & $43.8 \pm 3.5$ & $41.2 \pm 1.7$ & $44.3 \pm 0.18$ \\
\hline Monocytes count & $1.21 \pm 0.15$ & $1.18 \pm 0.16$ & $1.06 \pm 0.15$ & $1.03 \pm 0.016$ & $1.32 \pm 0.21$ \\
\hline Haemoglobin & $13.98 \pm 0.25$ & $14.4 \pm 0.22$ & $14.16 \pm 0.31$ & $14.7 \pm 0.53$ & $13.40 \pm 0.28$ \\
\hline Neutrophils & $42.18 \pm 1.63$ & $31.8 \pm 0.64$ & $76.3 \pm 1.68$ & $31.74 \pm 0.71$ & $43.42 \pm 1.21$ \\
\hline Eosinophils & $5.1 \pm 0.25$ & $5.1 \pm 0.25$ & $5.5 \pm 0.22$ & $5.1 \pm 0.25$ & $5.3 \pm 0.33$ \\
\hline R.B.C. Count & $6.05 \pm 0.24$ & $6.11 \pm 0.05$ & $6.17 \pm 0.05$ & $6.20 \pm 0.08$ & $6.72 \pm 0.24$ \\
\hline Platelet Count & $3.44 \pm 0.13$ & $3.72 \pm 0.11$ & $4.02 \pm 0.16$ & $4.19 \pm 0.13$ & $3.54 \pm 0.12$ \\
\hline Mean Platelet Value & $10.30 \pm 0.14$ & $9.73 \pm 0.16$ & $9.37 \pm 0.17$ & $10.10 \pm 0.18$ & $9.85 \pm 0.10$ \\
\hline Packed cell volume & $37 \pm 0.32$ & $35.3 \pm 0.10$ & $35.14 \pm 0.29$ & $36.8 \pm 0.21$ & $36.42 \pm 0.25$ \\
\hline Mean corpuscular volume & $54.4 \pm 0.17$ & $56.12 \pm 0.26$ & $54.72 \pm 0.31$ & $56.36 \pm 0.25$ & $55.24 \pm 0.16$ \\
\hline $\begin{array}{l}\text { Mean corpuscular } \\
\text { hemoglobin }\end{array}$ & $21.73 \pm 0.21$ & $24.32 \pm 0.27$ & $21.2 \pm 0.46$ & $24.2 \pm 0.44$ & $22.36 \pm 0.0 .40$ \\
\hline Red cell distribution width & $14.6 \pm 0.14$ & $14.3 \pm 0.17$ & $15.1 \pm 0.15$ & $14 \pm 0.42$ & $14.3 \pm 0.18$ \\
\hline
\end{tabular}

The results are expressed as mean $\pm S E M$, where $n=6$. SEM: Standard error of mean. $* P<0.05$, compared with control group.

toxic effect on the relative weight of the important internal organs in chronic toxicity studies.

Analysis of the effects of Chaturmukha Rasa on hematological parameters (Table 2) revealed Non-significant increase in WBC count at each of the dose level studied in the main study in comparison to the control group. However all the values were within the normal range. ${ }^{27}$ The test drug at all dose level did not affect the RBC related parameters. This clearly indicates that the test drug did not affect the cellular and non-cellular elements of the blood to significant extent. All the other hematological parameters were more or less near to normal which indicated that there is not major change after administration of the test drug.

Analysis of the effects of Chaturmukha Rasa on biochemical parameters (Table 3) revealed a significant increase in creatinine level, decrease in total serum protein, decrease in serum albumin except in TEDx 5 , minor decrease in serum globulin, significant increase in SGPT and significant decrease in SGOT except in TEDx5, significant decrease in alkaline Phosphatase and significant increase in blood sugar level. After discontinuation of test drug in the recovery group, the observed changes in glucose level, creatinine and triglyceride were almost same as seen in the recovery control group (Table 4).

The Histopathological studies of organs showed that Chaturmukha Rasa along with adjuvant at highest dose level exhibited mild to moderate changes in kidney and liver in comparison to the control group. Chaturmukha Rasa produced mild pigment deposition, fatty changes in epithelium and oedematous changes in kidney tubule (Figure 1). Chaturmukha Rasa TED $\times 10$ and TED $\times 5$ treated groups exhibited pigment deposition, mild necrosis and fatty changes in the liver in comparison the control group (Figure 2). 


\begin{tabular}{|c|c|c|c|c|c|}
\hline \multicolumn{6}{|c|}{ Table 4: Effect of Test Drugs on Biochemical Parameters in Rats Recorded During Chronic Toxicity Study. } \\
\hline Biochemical Parameters & Control group & TED & TEDx5 & TEDx10 & Recovery TEDx10 \\
\hline Creatinine & $1.3 \pm 0.20$ & $1.05 \pm 0.08$ & $1.13 \pm 0.06$ & $1.10 \pm .02$ & $1.21 \pm 0.12$ \\
\hline Total Serum Protein & $7.06 \pm 0.05$ & $6.91 \pm 0.18$ & $6.96 \pm 0.11$ & $6.83 \pm 0.10$ & $6.98 \pm .0 .06$ \\
\hline Serum albumin & $3.8 \pm 0.14$ & $3.4 \pm 0.21$ & $4.1 \pm 0.14$ & $3.2 \pm 0.15$ & $3.6 \pm .0 .16$ \\
\hline Serum globulin & $3.4 \pm 0.14$ & $3.3 \pm 0.15$ & $3.1 \pm 0.06$ & $3.5 \pm 0.15$ & $3.4 \pm .0 .06$ \\
\hline SGPT & $26.03 \pm 0.33$ & $73.2 \pm 1$ & $59.25 \pm 0.89$ & $16.2 \pm 0.27$ & $25.14 \pm .0 .25$ \\
\hline SGOT & $168 \pm 1.46$ & $32.1 \pm 0.83$ & $185.16 \pm 1.60$ & $12.65 \pm 0.29$ & $165.21 \pm .0 .04$ \\
\hline Alkaline Phosphatase & $73.2 \pm 1.47$ & $56.25 \pm 0.77$ & $16.2 \pm 0.32$ & $66.7 \pm 0.56$ & $60.80 \pm .0 .14$ \\
\hline blood sugar level & $128 \pm 1.23$ & $148.5 \pm 4.02$ & $145 \pm 6.79$ & $143 \pm 7.03$ & $130.32 \pm .0 .40$ \\
\hline
\end{tabular}

The results are expressed as mean $\pm S E M$, where $n=6$. SEM: Standard error of mean. $* P<0.05$, compared with control group.
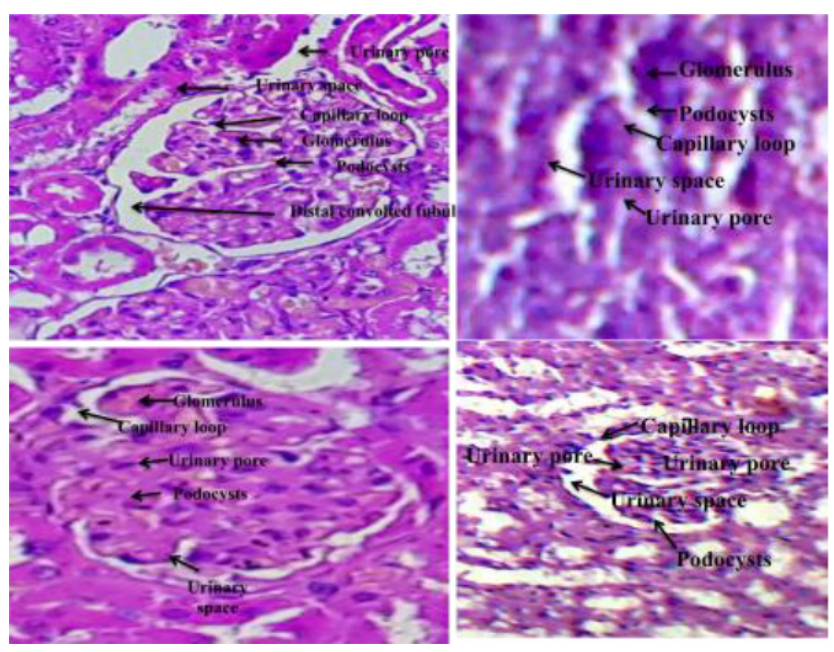

Figure 1: Histopathology of kidney tissues (x400 magnification) (A) Normal cytoarchitecture (control group), (B) edema and fatty changes (TED $\times 5$ ), (C) oedema, pigment deposition and fatty changes (TED $\times 10)$.
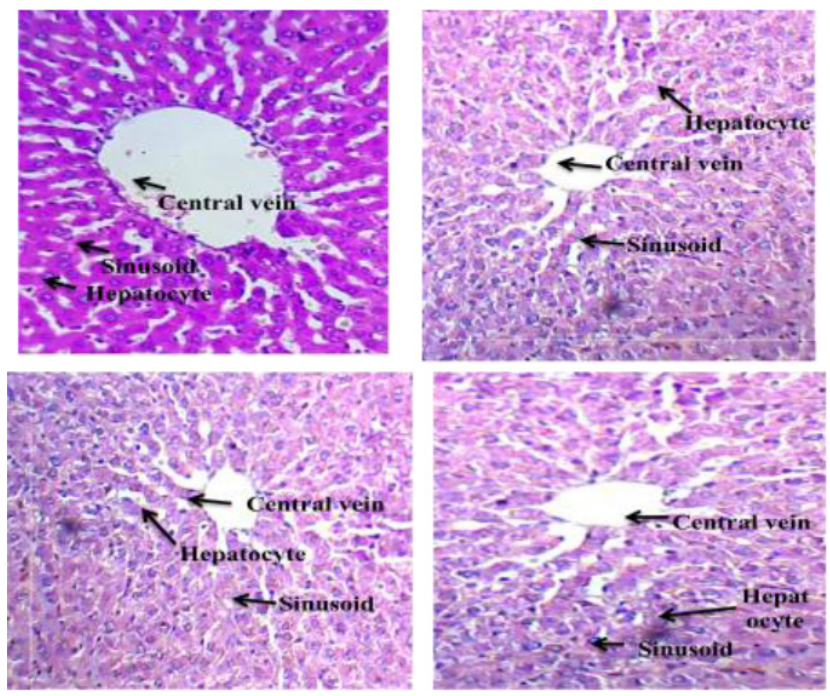

Figure 2: Histopathology of liver tissues (x400 magnification) (A) Normal cytoarchitecture (control group), (B) pigment deposition, mild necrosis and fatty changes (TED $\times 5$ ),

(C) pigment deposition, mild necrosis and fatty changes (TED $\times 10)$.

\section{CONCLUSION}

The results reiterates the fact that Bhasmas, despite their trace heavy metal content, are safe when appropriately manufactured and consumed as per directed instructions. Toxic effects of mercury were said to be neutralized in the presence of sulphur. ${ }^{28}$

In Ayurvedic system of medicine, Anupana (called vehicle, as a medium of administration) improves acceptability and palatability and helps in absorption of the main drug; additionally, it may also act as early antidote. ${ }^{29}$ Guduchi used as adjuvant in current study is having antioxidant property acts as hepatoprotective drug and has potential against aflatoxins and heavy metal toxicity. ${ }^{30,31}$

\section{ACKNOWLEDGEMENT}

The authors are thankful to Columbia Institute of Pharmacy for providing all the necessary facilities for doing this research work.

\section{CONFLICT OF INTEREST}

The authors declare no conflict of interest.

\section{ABBREVIATIONS}

TED: Therapeutic effective dose; IAEC: Institutional Animal Ethics Committee; $\mathbf{m g} / \mathbf{d}-$ Milligram/day; OECD: Organization for Economic Co-operation and Development; RBC: Red blood cells; Hb: Haemoglobin; PCV: Packed Cell Volume; MCV: Mean Corpuscular Volume; MCH: Mean Corpuscular Haemoglobin; MCHC: Mean Corpuscular Haemoglobin Concentration; WBC: White Blood Cells; \%N: Percentage Neutrophill; \%L: Percentage Lymphocyte; PC: Platelet Count; HDL: High Density Lipoprotein; VLDL: Very Low Density Lipoprotein; LDL: Low 
Density Lipoprotein; SGOT: Serum Glutamic Oxaloacetic Transaminase; SGPT: Serum Glutamate-Pyruvate Transaminase.

\section{REFERENCES}

1. Pandey RK, Tiwari RK, Shukla SS. Omics: A Newer Technique in Herbal Drug Standardization and Quantification. J Young Pharm. 2015;8(2):76-81.

2. Krishnamachary B, Rajendran N, Pemiah B, Krishnaswamy S, Krishnan UM. Scientific validation of different purification steps involved in the preparation of an Indian Ayurvedic medicine, LauhaBhasma. J Ethnopharmacol. 2012;142(1):98-104.

3. Kohli KR. Ayurvedic medicines and heavy metals issue $1^{\text {st }}$ edition Ayurveda Herit. 2005;5-6.

4. https://ayurmedinfo.com/2012/07/10/chaturmukha-rasa-benefits-dosageingredients-side-effects

5. http://naturalingredient.org/wp/wp-content/uploads/API-Vol-7.pdf.

6. Paget GE, Barnes JM. Toxicity tests, Evaluation of drug activities: Pharmacometrics, New York: Academic Press. 1964;205-10.

7. https://ntp.niehs.nih.gov/iccvam/suppdocs/feddocs/oecd/oecd_gl425-508.pdf.

8. https://www.oecd.org/chemicalsafety/testing/Revision-OECD-TG408repeated-dose-90-day-oral-toxicity-study-in-rodents.pdf.

9. http://ayush.gov.in/sites/default/files/File779\%20\%20\%204.pdf.

10. Pennock CA, Sellers DJ, Longdon KJ. A comparison auto analyzer method for the estimation of glucose in blood. Clin Chim Acta. 1973;48:193-201.

11. Talke H, Schubert GE. Enzymatic urea determination in the blood and serum in Warburg optical test. Klin Wochenschr 1965;43:174-5.

12. Slot C. Plasma creatinine determination: A new and specific Jaffe reaction method. Scand J Clin Lab Invest. 1965;17(4):381-7.

13. Roeschlau P, Bernt E, Gruber WA. Enzymatic determination of total cholesterol in serum. J Clin Chem. 1974;12:226-9.

14. Dominiczak M, McNamara J, Nauk M, Wiebe D, Warnick G. Measurement of high-density-lipoprotein cholesterol. Handbook of lipoprotein testing, $2^{\text {nd }}$ ed. Washington DC, AACC Press. 2000;819.

15. Fossati $P$, Prencipe $L$. Serum triglycerides determined colorimetrically with an enzyme that produces hydrogen peroxide. Clin Chem. 1982;28(10):2077-80.
16. Tietz NW. Text book of Clinical Chemistry. Philadelphia (PA), WB Saunders.1986;579.

17. Doumas BT, Arends RL, Pinto P. In standard methods of clinical chemistry, Chicago. Academic Press. 1972;7:175-89.

18. Wilkinson $\mathrm{JH}$, Boutwell $\mathrm{JH}$, Winsten $\mathrm{S}$. Evaluation of a new system for kinetic measurement of serum alkaline Phosphatase. Clin Chem. 1969;15(6):487-95.

19. Tietz NW. Clinical guide to laboratory tests. $3^{\text {rd }}$ edition, Philadelphia (PA). WB Saunders. 1995;76.

20. Burtis CA, Ashwood EA. Textbook of Clinical Chemistry. $3^{\text {rd }}$ edition, Philadelphia (PA), WB Saunders. 1999;652-1136.

21. Kabasakalian $P$, Kalliney $S$, Wescott $A$. Determination of uric acid in serum, with use of uricase and tribromophenol-aminoantipyrine chromogen. Clin Chem. 1973;19(5):522-4.

22. Pearlman PC, Lee RT. Detection and measurement of total bilirubin in serum with use of surfactants as solubilizing agents. Clin Chem. 1974;20(4):447-53.

23. Biggs HG, Moorehead WR. 2-Amino-2-methyl-1-propanol as the alkalizing agent in an improved continuous-flow cresolphthaleincomplexone procedure for calcium in serum. Clin Chem. 1974;20(11):1458-60.

24. https://www.unece.org/trans/danger/publi/unrec/12_e.html.

25. Timbrell JA. Principles of biochemical toxicology. London: Taylor and Francis Limited. 1982;446.

26. Gad SG. Animal Models in Toxicology. Boca Raton, CRC press. 2007;147-217

27. Sathya T, Murthy B, Vardhini N. Genotoxicity evaluation of certain bhasmas using micronucleus and Comet assays. Int J Alt Med. 2009;7:1-5.

28. Kumar A, Nair AGC, Reddy AVR, Garg AN. Availability of essential elements in bhasmas: analysis of Ayurvedic metallic preparations by INAA. J Radioanal Nucl Chem. 2006;270(1):173-80.

29. Dwivedi V, Anandan EM, Mony RS, Muraleedharan TS, Valiathan MS, Mutsuddi $\mathrm{M}$, et al. In vivo effects of traditional ayurvedic formulations in Drosophila melanogaster model relate with therapeutic applications. PLoS One. 2012;7(5):e37113.

30. Sharma V, Gupta R, Sharma S. Preventive effects of Tinosporacordifolia extract against aflatoxin-B1 induced oxidative stress in swiss albino mice. Asian J Pharma Clin Res. 2011;4(4):49-55.

31. Sharma V, Pandey D. Beneficial Effects of Tinosporacordifolia on blood profile in male mice exposed to lead. Toxicol Int. 2010;17(1):8-11.

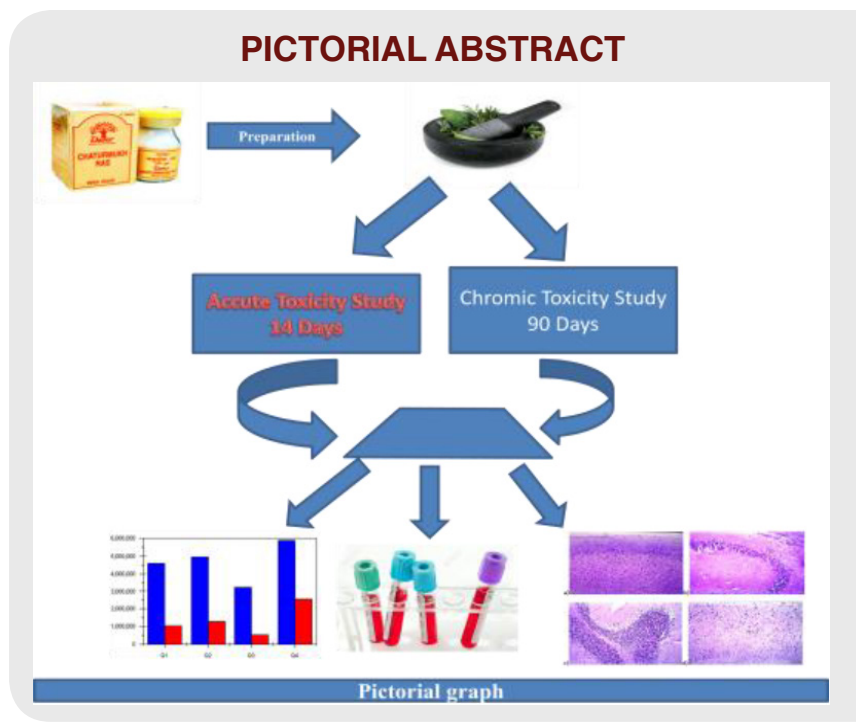

\section{SUMMARY}

The above study concludes that Chaturmukha Rasa with adjuvant is nontoxic on acute administration at a maximum oral dose level of $2000 \mathrm{mg} / \mathrm{kg}$ in female rats. However, on chronic administration of test drug for $90 \mathrm{~d}$ produced mild to moderate adverse changes in the kidney and liver of rats at TED $\times 10$ dose levels, equal to which could never be applied in clinical conditions. Chaturmukha Rasa at TED dose does not have toxic potential. Thus we may conclude that Chaturmukha Rasa prepared as traditional method is safe at TED dose when administered orally. 


\section{About Authors}

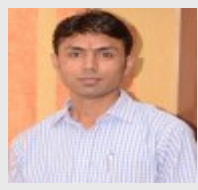

Shiv Shankar Shukla is Presently working as Professor, Department of Quality Assurance at Columbia Institute of Pharmacy Raipur, C.G. Author's areas of interest includes standardization of herbal medicine, chemical fingerprinting method development and also working on analytical identification and isolation of molecules from herbal origin.

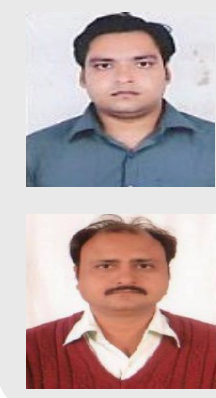

Raj Kumar Tiwari is currently working as Ph.D. Research Scholar in Columbia Institute of Pharmacy, Raipur, C.G. Author's area includes CNS Activity, Phytomedicine evaluation, Antidiabetic activity of herbal formulation.

Dr. Ravindra Pandey is presently working as Professor, Department of Pharmacognosy at Columbia Institute of Pharmacy, Raipur, C.G. Author's areas of interest is research activities in conventional medicine system, standardization and chemical fingerprinting method development of Ayurvedic and Herbal Formulation.

Cite this article: Sharma A, Tiwari RK, Sharma V, Pandey RK, Shukla SS. Toxicological Studies of Chaturmukha Rasa, an Ayurvedic Formulation. Indian J of Pharmaceutical Education and Research. 2019;53(4):688-94. 